\title{
PROJETO DE REQUALIFICAÇÃO DA ORLA DA LAGOA DE PIRATININGA, NITERÓI, RIO DE JANEIRO
}

\author{
MARIA EDUARDA RADLER DE AQUINO | UFRJ \\ VIRGÍNIA VASCONCELLOS, Dra. |UFRJ
}

\section{INTRODUÇÃO}

Este artigo apresenta um recorte da pesquisa realizada para elaboração do Trabalho Final de Graduação, cuja proposta é um Projeto de Requalificação da orla da Lagoa de Piratininga, na Cidade de Niterói, Rio de Janeiro, Brasil.

O trabalho partiu da identificação e delimitação do trecho da orla, que vem sofrendo com problemas gerados pelo abandono e pela ocupação irregular, como redução do espeIho d'água, devido ao assoreamento da Lagoa causado pelo lançamento de lixo e resíduos de construções, de esgoto sanitário, entre outros, até o projeto de requalificação da área.

A Lagoa de Piratininga é uma das microbacias da Região Oceânica e a maioria das nascentes dos corpos hídricos que contribuem para a sua existência se localiza em áreas cobertas por florestas em bom estado de conservação. Os percursos naturais dos rios e córregos que integram esta sub-bacia foram alterados e canalizados, o que contribuiu para a deterioração da Lagoa e sua borda.

A Lagoa está passando por um acelerado processo de expansão residencial e comercial. O trecho da orla, onde se propõe a requalificação vem sendo ocupada por uma população de baixa renda, ao longo dos anos; na maioria pescadores que tiram da Lagoa a sua fonte de renda e por trabaIhadores do setor terciário. Esses moradores são carentes de espaços públicos voltados ao lazer e precisam, também meIhorar as condições de acesso às moradias e à própria Lagoa.

\section{METODOLOGIA}

Como método, o trabalho parte de um embasamento teórico-conceitual, levantamentos bibliográficos, com coleta de dados em publicações acadêmicas, plantas da Prefeitura e referencial de projetos; levantamentos de campo, a partir de visitas in loco, com observações diretas não participativas, registros fotográficos e Base Google Earth.

Os dados foram tratados a partir da confecção de mapas (biofísicos, figura e fundo, gabarito e uso do solo), cortes e desenhos. Foram utilizados, ainda, programas computacionais, como AutoCad e PhotoShop.
Nos levantamentos foram constatados os principais problemas e necessidades dos moradores e o potencial paisagístico e ambiental do local. Foram realizadas análises morfológicas e mapeados os principais elementos da forma urbana, identificados no local por meio de registros fotográficos e do redesenho de alguns mapas da Prefeitura para atualização de dados, além de serem identificadas e respeitadas as massas vegetadas que permitem a sobrevida e a recuperação futura do ecossistema lagunar.

\section{RESULTADOS}

O projeto de requalificação da orla inclui a reformulação do traçado geométrico das vias, melhoria dos passeios (acessibilidade), localização e especificação de arborização e mobiliário, além da introdução e/ou reformulação de espaços de socialização já existentes, que visam, sobretudo, a atividades educativas, culturais e esportivas, guardando as características ambientais (vegetal e animal) e os atributos da paisagem do local. Ao mesmo tempo cria novas áreas de lazer comunitário e espaços para permitir a continuidade da pesca, que se configura como a principal atividade de subsistência da comunidade. A proposta visa, ainda, à reintrodução da flora nativa nas margens da Lagoa, auxiliando a recuperação de micro biomas (recomposição da fauna e melhoraria do conforto ambiental).

\section{REFERÊNCIAS}

LAMAS, José M. Morfologia urbana e desenho da cidade. 7. ed. Rio de Janeiro: Fundação Calouste Gulbenkian, 2010. 592 p.

TRANCIK, Roger. Finding Lost Space: Theories of Urban Design. 1. ed. USA: John Wiley \& Sons, june 1986. 256 p.

Prefeitura Municipal de Niterói. Atlas das Unidades de Conservação do Município de Niterói [arquivo digital]. Niterói: Pedro Bittencourt, 2018. 101p. 
